\title{
TIME, SENSE AND MEANING IN THREE VOTIC SONGS (WITH REFERENCE TO ESTONIAN AND SETU ADDITIONS)
}

\section{Madis Arukask}

\begin{abstract}
The article investigates Votic, Estonian and Setu Kalevala-metric folk songs, which describe a dialogue between a living person and his or her deceased relative. The analysis centres on religious truth in poetic texts, relying on corresponding approaches by Ülo Valk and Aado Lintrop. As the observed texts are no longer mytho-epic stories or laments, the question about the meaning in lyro-epic discourse is discussed and particular attention is paid to the changes in concepts of time, the plot and characters of the songs. The author introduces the key concept 'epiphany' as a tool constructing meaning and merging the actual situation, the song text and personal emotions into a creative whole for the singer and/ or the audience.
\end{abstract}

Keywords: folk belief, Estonian folk song, Votic folk song, Kalevala metre, lyro-epic dicourse, epiphany

\section{INTRODUCTION}

Kalevala-metric poetry is a gratifying source for the study of the earliest pre-Christian religious stratum of the Balto-Finnic peoples. It has been presumed that among these peoples, the Kalevala metre as a specific contentual and formal entity (as a code) has for millennia been the medium for handing down culturally and religiously significant information (cf. Kuusi 1994: 41). As would be expected, this viewpoint has been emphasised particularly by Finnish scholars on the basis of the Karelian epic songs which have retained a great deal of the so-called Kalevala mythology - a phenomenon supported by the stability of the genre.

The Kalevala-metric poetry recorded over the last few centuries among such Balto-Finnic peoples that "stood closer to culture", has no memory of such gems. Here, life as reflected in the songs and life as actually lived have been interwoven in a different manner. Due to historical and gender-specific factors, the Estonian, Setu, but also Votic song traditions are dominated by a feminine and lyri- 
cal mode of imagination, and it takes some focusing of the eye to discern the rudiments of myths there. The songs of the 19th and 20th century certainly no longer present myths but, at best, an everyday didacticism woven into poetic forms that has supported creative and syncretic agrarian worldview where the Christian and pre-Christian elements are holding their relatively peaceful, though occasionally transfiguring dialogue. Over the centuries, the more outspoken understandings of religious reality have been shifted into the prose genres where they found more flexible expressive surroundings than those offered by the rather thought-conserving Kalevala-metric song.

The statement that the Kalevala-metric epic or lyro-epic songs record an older mythology only holds as long as we regard the genre as a researcher-centred ideal type. In that case we are certainly justified in speaking about ancient folk song as an idealistic reflection of primordial truths, a superhuman phenomenon in itself. This path is relatively safe and well-trodden. The situation appears quite different if we view the specific songs collected as cognitive categories - as phenomena that may have had a relatively unique purpose or function in their specific time and space. If we adopt this approach, we shall immediately be in trouble when working with texts recorded in archive documents, since traditionally, it is indeed only the text that has been recorded, not its surrounding reality nor, even less, its vague backgrounds. From the intertextual viewpoint, each text is merely a fragment of the whole tradition. Yet each text is also a fragment of a personality, of an individual; and for the researcher, it is also an instrument for comprehending one individual entity or another and for reflecting it within a given traditional space.

\section{ESTONIAN “ON MOTHER'S GRAVE” AND ITS "RELIGIOUS TRUTH"}

Regarding the Kalevala-metric song repertoire, we can thus, on the one hand, speak about a phenomenon stretching over a considerable length of time within which each individual born into the tradition has had to position himself, together with his particular cultural background and individual preferences. From the religious point of view, what interests us in the following is the above-men- 
tioned interaction between Christian and pre-Christian elements, from a comparative perspective also the possible religious context of similar songs recorded from the other Balto-Finnic peoples. In the present paper, we consider the song type "On Mother's Grave" and other texts related to it that have, in recent years, become objects of lively debate among Estonian scholars. Let me present here some Estonian examples of the text:

Ema haual

Meie kaksi vaestalasta lähme jaanipäe kiriku.

Sa lääd isa haua peale, ma lään ema haua peale, ${ }^{5}$ teine teise haua peale. Teine nutab, teine noorsub, teine pühib teise silmad.

"Tõuse üles, mu emake, tõuse üles, mu isake!

${ }^{10}$ Tõuse mu pead sugema, annivakka valmistama, kerstukaanta kinnitarna!"

"Ei või tõusta, tütar noori! Muru on kasvand mulla peale, ${ }^{15}$ aruheina haua peale, kullerkupud kulme peale, sinililled silmi peale.

Jumal su pead sugegu, annivakka valmistagu, ${ }^{20}$ kerstukaanta kinnitagu." ERLA II 2 : 611, No. 3370; H II 54, 183/4 (77). Collected in 1895 from Paide parish.

Avanenud hauad

Näiu mängive mäella, sinirinda rinnakulla, kudruskaala kallakulla. Visas kullasta kunada,
On Mother's Grave

We two orphans

Are going to the church on St. John's Day.

You are going to the father's grave, I am going to the mother's grave, Each of us to the other grave.

One of us is crying, other weeping, One sweeps the eyes of the other. "Wake up, my mother, Wake up, my father!

To comb my hear,

To prepare my dowry, To fasten up the chest!"

"I cannot wake up, my young daughter! Grass has grown on the ground,

Fescue grass on the grave, Globe-flowers on my brows, Blue anemones on my eyes. Let God comb your head, Prepare your dowry, Fasten up the chest." 
${ }^{5}$ visas karrasta kadsada. Threw a tinsel one.

Koes see kuna jooskenessa Where the stick was running või see kadsa karganessa? Or the tinsel one skipping?

Kuna joosk kirikuteeda, The stick ran by the church-road, kadsa karas kalmuteeda. The other skipped by the

${ }^{10}$ Valla lei kiriku-usse, katki põruts kalmukaane. Mis säält seest silmätive või säält vällä välpsätive? graveyard-road. Emä ennitse liiniku, ${ }^{15}$ esä karditse kasuku, velle kulditse kübäre, sõtsi siidileidikese nii säält seest silmätive, nii säält vällä välpsätive.

Broke open the door of the church, Tore open the cover of the grave.

What was there to see, What was appearing?

The one-time shawl of mother, The tinsel coat of father, The golden hat of brother, The silky dress of aunt This was there to see, That what appeared. ERlA II 2 : 618, No. 3383; H I 2, 109 (8). Collected in 1889 from Halliste parish.

Songs of this type are very popular in the Estonian tradition; Ülo Valk in his treatment has called them visionary songs and also necromantic poetry (2000: 253,264$)$. Trying to see the truth and the human being behind the poetic imagery, Valk connects these songs with the basic Christian conception of the soul's resurrection after death, which may have reached Estonia around the 13th century, when the country began to be more thoroughly Christianised. Admitting ignorance of what may have been actually going on in the consciousness of the singers, Valk nevertheless cannot see how else could they have understood the songs: "Hardly could the singer have addressed his or her dead father or mother, asking them to wake up, if (s)he hadn't known that at least in principle, resurrection was possible" (ibid.: 259). On the other hand, when commenting on the appeal to wake up, Valk observes that "in the context of Lutheranism, the song sounds vaguely heretical since the dead would be expected to sleep soundly till the Last Judgement" (ibid.: 261). That is why, in Valk's opinion, this kind of treatment must be a pre-Lutheran phenomenon (Lutheranism began to spread in Estonia after the year 1523) rooted in the Catholic visionary literature that spread widely all over Europe. 
Ülo Valk's basic standpoints have been contested by Aado Lintrop, who maintains that it is impossible to understand these songs from such narrowly Christian grounds since communication with the dead is a central conception in many religions (2001: 301). Lintrop also warns that the resurrection image should not be over-naturalised, and invites to interpret the lyro-epic Kalevala-metric song as a poetic text rather than an outspoken (religious) description of reality. Discussing the possible Christian elements in the song more closely, Lintrop will rather see their origins in the Protestant period than in the Catholic visionaries - a view supported by the song's moral, to put your hope only in the God, not in the human deceased ones (ibid.: 310-312). The prevailing presence of two orphans - in the older songs, we more often meet the formulaic four virgins - and the implication that St. John's Day is the most important general festival of commemoration of the dead after Christmas in Estonia, also seem to support Lutheran origins.

Still wishing to discern the person behind the texts, both Valk and Lintrop ask about the songs' performing situation. Especially in Protestant contexts, the singing of such songs may have functioned as an act of lamentation, serving as a means for addressing the world beyond while on the grave. Thus, it really is necromantic poetry. A possible connection with wedding customs meets the eye - in the above texts, too, the orphan asks her mother to come and help her make her dowry. In Lintrop's view, it is not altogether impossible that the symbolic language of the song may have signified not only a truly parentless child by that "orphan", but also a bride during the rites of passage (2001: 305). In the Russian Orthodox Setumaa, as well in the Orthodox Ingria (see Nenola-Kallio 1982: 133-135), lamenting on the grave (if bride's parent was dead) is known to have formed part of traditional wedding celebrations. At the same time, the Setu song tradition indeed knows not only lamentations but also songs that describe communication situations with the world beyond, both song types employing similar poetic devices. It seems probable, however, that functionally the songs were not as tightly bound to specific situations as the lamentations. It is likely that songs about two orphans could also be sung by maidens whose parents were still alive (instead of only by imaginary choirs of orphans), and naturally also by grown-ups whose parents had deceased at a more natural time of life. 


\section{THE VOTIC SONGS}

In addition to the Estonian (and adjoining Setu) material, mention should also be made of the relevant Votic songs which belong to overall Western Ingrian Kalevala-metric poetry corpus (see Salminen 1929: 17-23) and not many of which have been written down. The third Mid-Ingermanland volume of Suomen kansan vanhat runot (Ancient Poems of the Finnish People; see SKVR) includes three similar, obviously Votic song texts that have been collected at different times by different scholars. Let me cite these here, too:

1.

Nyt saab lunta uutta lunta, It is snowing now, new snow is coming, Valab vasesta ragetta It is hailing copper flakes

Uue turgu uulitsale, Vana torgu vaanijale, ${ }^{5}$ Vassese paja ettee. To the street of new market, To the square of old market, Tuleb neljä neitsykkeissä Kaikki kŏrva rengaissa, Puolet puokka toimikkaisa, Töinen puoli poimituisa. 10 Juttevat toine toiselesa: Milla noimma mäntsjämää, Kulilago vai kalilla.

Kuli kukku taivaase, Kali veeri kalmoteele, 15 Veerakkot kjerikkoteele, Veeri velle tjääpä pääle.

Oi velvyt nimetä minua, Arvaele aigoani, Veere velle kjäpä pääle. ${ }^{20}$ Oi velvyt emäni lahsi, Mene koole kotona! Tseehuta pata munea, Vaali vakka piirakoita, Too munat mulla pääle, ${ }^{25}$ Piirakaiset kjääpä pääle! Nimetä minu nimeni, Arvaa minu aigvoni, In front of copper window. Four virgins are coming, Everyone with ear-rings, Half of them with twilled belts, Other half with plaited belts.

They are talking themselves:

How shall we play,

With sticks or with cudgel.

The stick fell to the heaven, The cudgel rolled to the grave-road, The rolling ones to the church-road, Rolled on the grave of the brother.

Oh brother, appoint my name

Mention my age, Roll on the grave of the brother. Oh brother, child of my mother, Go home, be at home! Boil a cauldron of eggs, Make a bushel of pies, Bring the eggs on the ground, The pies on the grave! Appoint my name, Mention my age, 
Mi panna minu nimessi. What will be my name.

Ivana minu nimessi. Ivan will be my name.

SKVR IV $_{3}$ : 717, No. 4632. Recorded by Elias Lönnrot in 1844 from Anna Ivanovna in Kattila manor.

2.

Kalmoiza örjännü welli

Sâb lunta, ûtta lunta,

Walab wazgessa ragëhta,

Uwwề turgî̀' ûlitsale, Wanâ' turgû' wainiale,

${ }^{5}$ Wazgesê' pajâ' etêse.

Tuli nell'ä neitsükäissä

Wazgesê' pajâ' etêse,

Juttõ tõinê' tõiselesa:

"Milä nõisemm

mänčämầse,

${ }^{10}$ Kulilako wai kalila?"

Kuli kukkui taiwâse, Kali wêri kalmo-têle, Wêrakko čerikko-têle, Wêri well'ế' čấp $\hat{a} '$

$$
\text { pầle: }
$$

15 "Oi welwüt emäni lahsi, Wõitko nõissa ja ületä, Anna čấpässä čätüet, Sõrmet lîwassa wiritä."

Well'i wasô' wassaelëb: 20 "En wõi nõissa, en ületä, Oi sõza, emäni lahsi, Mene kuo', õle kotona, Čihuta pata munõja, Waali wakka pîragoita, ${ }^{25}$ Too munat mullâ'

$$
\text { pầlê', }
$$

Pîragaiset čấpâa $p \hat{a} l e ̂$, Nimetä minû' nimeni, Arwâ minû' aigoeni!
Brother's slavery in the grave

It is snowing, new snow is coming, It is hailing copper flakes,

To the street of new market, To the square of old market, In front of copper window.

Four virgins came, To the front of copper window, They talked themselves: "How shall we play,

with sticks or with cudgel?"

The stick fell to the heaven, The cudgel rolled to the grave-road, The rolling one to the church-road, Rolled on the grave of the brother:

"Oh brother, child of my mother, Could you wake up and rise, Give your hands from grave, Spread your fingers from sand."

The brother is answering:

"I can not wake up and rise, Oh sister, child of my mother, Go home, be at home, Boil a cauldron of eggs, Make a bushel of pies, Bring the eggs on the ground,

The pies on the grave, Appoint my name, Mention my age! 
$\mathrm{SKVR} \mathrm{IV}_{3}$ : 730-731, No. 4657. Recorded by August Ahlquist in 1854-1855 from Anna Ivanovna in Kattila manor.

3.

Sa'ab sa'ab uutta lunta, Valab vasessa ragehta Uuve lidnaa uulicalle,

Vassezee pajaa etee.

${ }^{5}$ Tulevad nellä neicykkäissä,

Keikk on kervare $\eta$ kaiza; Jutteevad teine teizele: "Millä neemma män čmää, ${ }^{10}$ Kulilla vai kalilla?" Kuli kukku taivaassa, Kali kajahti kalmossa. Vierakko čerikoo teetä.

Vieri vellee čääpää pääle. ${ }^{15}$ Velli čääpäss čärähti, Maa alta ante äälee:

"Oi sesar, emani lahsi, Elä riko uhsiani! Eväd ele sinu tehyd, ${ }^{20}$ Uhsed on tehyd Tuonee tehyd

I Tuonee čirvee čirjutetud. Mene kotoo, ee kotona, Vaali vakka piiragoita, Čyhzetä anee-muneita; ${ }^{25}$ Kucu kurget veerazii, Kurči tuob kuus kurnikkea, Särči tuob seitsee säylämää.”
It is snowing, new snow is coming, It is hailing copper flakes, To the street of new town, In front of copper window. Four virgins are coming,

Everyone with ear-rings;

They are talking themselves:

"How shall we play,

With sticks or with cudgel?"

The stick fell into heaven, The cudgel cannoned into grave.

The rolling one rolled to the church-road.

Rolled on the grave of the brother. Brother exclaimed from the grave, Made a voice from under the ground: "Oh sister, child of my mother, Do not break my doors! These are not made by you, The doors are made by Tuoni

And Tuoni's axes are patterned. Go home, be at home, Make a bushel of pies, Cook the goose-eggs, Invite the cranes as guests, The crane brings six fish pasties, The roach brings seven dishes". $\mathrm{SKVR} \mathrm{IV}_{3}: 770-771$, No. 4778 . Recorded by Vihtori Alava in 1901
from old woman Vasilissa in the village Pummola of Kattila manor.

The first two texts quoted here were collected from the same person - a woman called Anna Ivanovna from Kattila. One "end" of 
that settlement situated at the notional centre of the Votic habitate, was at that time certainly still inhabited by a vigorous Votic community. The third text was also written down near Kattila. The two texts collected from Anna Ivanovna (in the years 1844 and 18541855 , respectively) are separated by ten years, a period long enough to offer material for studying the different compositions and the creative and mnemonic processes of the singer (about Anna Ivanovna as a performer of laments see Nenola-Kallio 1982: 237-241). Also, the collectors - Elias Lönnrot and August Ahlquist - are different, as well as the orthography they use. The third text was written down by Vihtori Alava half a century later, in 1901.

Compared to the Estonian songs, these texts reflect, as would be expected, the Russian Orthodox background and customs of the Votes - here, people do not go to the graves on St. John's Day, which in Estonia is one of the most important commemoration days in popular Lutheranism. The Votic texts speak about snow falling - which may be taken, if we think wishfully enough, as a hint at the traditional souls' visiting time (after the summer period of outdoor works) when it often rains or snows. While in the Estonian songs, the graves are visited by the two orphans or an unspecified number of maidens, and in the Setu songs generally by a single individual, the Votic songs always speak about the more archaic, formulaic "four virgins". In the Kalevala-metric songs, the four virgins originally appear to have indicated female mythological beings active in the heavenly sphere - in the Setu mythic songs, for instance, they are to be found somewhere in the clouds. Although it may be difficult to identify them as such Valkyries in the given Votic texts, it seems obvious that the virgins (and the story together with them) cannot have their origins in so late a period as the arrival of Christianity in Estonia, suggested by Ülo Valk as the Estonian songs' birth period. Another difference between the wailing orphans of the Estonian songs and the Votic "four virgins" is the emphasis on the latter's magnificent jewellery - at least in two of the above texts.

Looking for some outspoken instructions concerning worldview or particular behaviour in the Votic songs (in the manner of Ülo Valk), we would, no doubt, find that the deceased are telling the quick: do not put your hope in our resurrection, just observe all the prescribed (commemorating) customs. The endings of the songs are 
ethnographically correct, mentioning the dishes that were traditionally connected with commemorating the dead - eggs and pies. Anna Ivanovna's songs include no allusions to a superior divine will; Vassilissa's song mentions only the obstructive patterned doors made by the ruler of the realm of the dead, Tuoni. Noteworthy is the invitation, in the latter presentation, to the crane and the roach to come to the grave to commemorate the deceased. It is difficult to say whether these latter represent someone's poetic synonyms or rather rudiments of totemism. Väinö Salminen sees here a theme of invitation of deceased souls to participate (1929: 23). The style of the Votic songs rarely features the ardent lyricism characteristic of the Estonian songs. Rather, it would seem as if the four virgins (or one of them) were trying, through a ritual game, to establish magical contact with the deceased, meeting, however, a sobering response. Not knowing the songs' exact performance or usage contexts in the Votic tradition, we can hardly expect to gain a correct understanding of their content. Possibly they may have been used in the weddings with laments as it is usual in the Russian Orthodox folk traditions. In Lutheran Estonia, the disappearance of the former lament tradition may well have left a void in the genre system readily filled by this kind of necromantic poetry. However, it seems that this did not happen in the Orthodox Votic and Setu traditions where the laments survived and obviously enabled the given plot to retain its original magical and ethnographic content. Accordingly, the texts are not so much focused on later religious nuances but rather convey routines of customs or (if you wish) natural law. If there is anyone at all asking for help in the Votic songs, it is the deceased brother in the grave desiring to be commemorated with customary observances.

Apparently storylines tend to survive the various competing worldviews, not the other way round. In the area of the Kalevalametric poetry, the same primordial song forms have acquired different meanings in various later cultural backgrounds (cf. Siikala 2002: 325-326). Orthodox village Christianity probably did not lead a person (especially a 19th century Vote without any knowledge of the Church Slavonic) to the path of individual theological contemplation, but rather stressed the need to observe communal customs in order to retain a sense of community. It has been suggested often enough that even in Estonia, a deeper and meaningful understand- 
ing of Christianity based on the knowledge of the Gospels only won ground in the first half of the 18th century, in connection with the movement of Brethren Congregations. Therefore it seems even less likely that the sole and basic subject of the above Votic songs could have been the idea of bodily resurrection on the Day of Judgement (even though various sects of evangelical Christians had by that time long been preaching this message around St. Petersburg).

The Votic song texts begin with the image of snow falling on a copper window. In a sense, the songs really are "sojourns at the window", visits to the borderline between this world and the next, glances into the world beyond. And it is not at all easy to say whether their basic emotion is an individual's mystical fervour or rather, perhaps, the calmer and more matter-of-fact serenity of a seer, täätäjä who respects the rules of magical communication.

\section{TIME, STORY AND PERSONALITY}

These songs are like stories for us. They unfold in front of our eyes like chains of events and then come to an end, forcing us to adopt an attitude towards what we have heard (or nowadays more commonly read). It is clear that in the last few centuries, the song tradition of the Southern Balto-Finnic peoples has been increasingly influenced by lyrical imagination. In lyrical discourse, however, the individual interpretations that are allowed to find expression in the text, are far fewer than those left behind it - at least this is the case with the Kalevala-metric lyrics and lyro-epics. Regardless of all, it remains very difficult for us to outline unequivocally the aim of the Kalevala-metric songs. It seems the songs want to communicate or teach, sometimes to narrate something. But the songs have also helped to settle things quite outside the song world, things that remain beyond the text, the letters and written lines in front of us. Unlike the products of literate cultures or, as we term them nowadays, fiction, it seems that no Kalevala-metric song current in the oral culture ever started from its own beginning - within the tradition, each song revived the culturally acquired associative intertextual relations preserved in the corpus as a whole. In like manner, no song really ended where it was finished. 
Recalling the epical "youth" of the Kalevala-metric poetry we must remember the specific feature of epic reciting: that usually, no epics have anywhere been performed from the beginning to the end (cf. Honko 1998: 31-32). It is even possible that epics as completed narratives were composed only after the advent of literacy, scribbled up as "stories" and bound into books. Even though the traditional stories were familiar to everyone, their adding up into texts has been a rather more fragmentary process. Another disputable question is, whether the events associated with some hero - which in the characteristic linearity of literary epics follow in sequences readily understandable to the modern reader - had the same temporal significance for inhabitants of an oral culture, who could frequently hear (the more popular) parts of the main story in various ritual situations but connected them probably with an event or a situation (i.e. with space) rather than with the (hi)story (i.e. with time).

Naturally, what we see here are reminiscences of the mythical origin of epics. In a performing culture of this kind, heroes are not dead but rather permanently alive. The time-manipulating (not time conception) skill characteristic of the epic tradition is pretty well comparable to that of the Tralfamadorians in Kurt Vonnegut's novels, with the sole difference that the inhabitants of Tralfamadore were able to live in the moment that pleased them while at the same time knowing each detail of the birth and fate of themselves and of the Universe. For a person inhabiting the traditional world of the Older Edda, Ragnarök was both ahead and past, Baldr both alive and murdered. Perhaps the continuations of stories of a certain type, prophesying the return (usually upon some omen or sign) of a cultural hero that had traditionally died at some point, actually came into being because of the concern that people began to feel about termination and completion after they had been trained to think linearly.

Thus, the performing in oral tradition of more or less epic (that is, lyro-epic) songs in periodic repetition, continuing through the calendrically circular human life, may have liberated man from the need to see or comprehend what he heard linearly - in the only manner we can understand. Yet at the same time we are far from understanding precisely where the fault line between different interpretations of time could run. Could it, in the Balto-Finnic tradi- 
tions, be located in the lyro-epic Kalevala-metric song stratum? It is obvious that in Ingria, Estonia and Setumaa, the lyro-epic songs are no longer quite as centred around nominally identified heroes nor woven into more or less related cycles through the latter as they are in the masculine epics of Karelia. The dialogic nature of various texts has rather consisted in minor poetic episodes and their associative meandering from one song into another, carrying along cultural allusions and more specific meanings difficult to capture in the modern times.

Arne Merilai has discussed the Estonian ballad and temporal models in the Kalevala-metric poetry. In doing so, he observes: "No matter what the story is about, its defining metaphysical topic is time" (1996: 15), maintaining at the same time that in ballads, we no longer meet neither mythological circular time nor the sense of eternity characteristic of religions. Merilai places the fault line in time experience between the ballad-type Kalevala-metric poetry and its developmentally earlier form prevailed by a parallelistic time conception. "It must obviously be presumed that such (i.e., the Kalevala-metric) ballads are the locus where the conflict between two historical modes of time cognition - the ebbing parallelistic and the ground-winning linear models - finds expression," he observes (ibid.: 19). It must be noted that here we are, after all, speaking only about the cognition of Kalevala-metric songs preserved till our days and containing (temporal) parallelism, not about the texts as such. Merilai further writes:

Regardless of the ancient tendency towards parallelism, the Estonian Kalevala-metric ballads still basically flow linearly, that is, from the past through a more detailed treatment of the present into the future. Such linearity could not possibly have been the temporal background of pre-ballad Estonian folklore but must probably have spread here through Scandinavian and German contacts. (Merilai 1996: 19).

Thus, we can conclude that Kalevala-metric poetry is a phenomenon standing on the borderline between different ways of thinking, but the crossing from the old (mythical) world view to the new (fictional and modern) one is by no means easy and a great amount of very different material accumulates around the border. 
Something has happened to time in Kalevala-metric poetry. It is either "made" very easy for our modern cognition or "left" quite incomprehensible for us. Writing about the products of an oral culture, John Miles Foley (see, for example, 1991: 7ff.) has repeatedly emphasised their metonymic character. By metonymy, he keeps in mind their natural state of being - a situation in which the tradition with its idiosyncrasy can economically inform the community familiar with it, explaining and demonstrating far less than required for the modern reader who often sees mere lifeless fragments of a one-time entirety of tradition.

Speaking about time, what chances do we have for reconstructing a more or less likely idea of its peculiarities in the old songs, in order to gain a better understanding of these songs' inner dynamics? First, we must probably give up all attempts to establish a common temporal movement between different lyro-epic texts. Let us consider the songs as single units, as isolated stories, temporally - as adventure stories or thrillers, not mythical "science" any longer. Regardless of everything, the fictional world of a single story nevertheless draws on an image of the real world without standing on a different level from it, as would be supposed about the mythical world which can only be approached through serious ritual activity or an altered state of consciousness. "The logic of the fictional world is based on the logic - the chrono-logic - of the real world, the events are connected temporally and causally there" (Annus 2002: 17). Yet if fictional texts are, probably for artistic reasons, often especially fond of arranging events in some other than temporal order, the same cannot very well be said about the lyro-epic Kalevala-metric songs which, with their few episodes, are usually anything but complex about the ordering of events.

In her thematic monography "How to Write Time", Epp Annus has pointed out the paradox of time usage in narrative: "a narrative that has, as the main axis of its existence, the axis of time, and that exists only so far as it moves ahead in time, nevertheless appears to desire the stopping of time" (2002: 17). The message, when we try to make sense of this, seems to be that for the observer, the important thing about any story is to follow its unfolding and development in time. Contemplating the events, looking into them and ascribing meaning to them, on the other hand, always requires a 
stop. Searching for an answer to the question of "either now or continually" seems to be one of the ways whereby we might gain a better understanding of the conception of time in Kalevala-metric songs. The first thing we should try to find out here would be the question, what was the one-time tradition oriented at? Was it pushing forward hastily like a thriller or rather lingering continually to ascribe importance and meanings?

The different nature of myth and non-myth, a truthful text and fiction, has also been analysed by Yurii Lotman. He writes:

Unlike fiction, a story of the mythological type does not form on the chain-of-events principle but rather "folds up" like a cabbage where each leaf repeats with certain variations all the other leaves, and the original story nucleus is through endless repetition woven into an entity that remains open to further growth. The absolute principle of isomorphism reduced all possible stories to one Single Story - the invariant of all myth-narrative possibilities and of all single episodes of all these possibilities. (Lotman 1991: 321; 2001: 670).

If the Kalevala-metric lyro-epic poetry no longer fulfils the truthproducing function of a myth, we can only presume that it consists (in regard both of its time conception and modes of thought) of isolated linear stories - although, considering the principle of intertextuality, this cannot be accepted absolutely, either.

Lotman observes that "texts created in different spheres of human activity bore significant differences both structurally and functionally" (1991: 323). But if we admit that in the case of lyro-epics, we are handling a genre that had evolved over a very long time span, undergoing repeated changes and distortions, the answer given here apparently to the whole problem is not sufficient, we would like to know more about it. Departing from Lotman's observation, the whole question would seem to "resolve" itself in the perception that essentially non-mythical events - all sorts of "reports of daily life" that were considered worthy of memorising - were transformed into the above-mentioned "cabbage" shape. This, however, naturally meant that a single past event acquired narrative form through mythicisation rather than through fictionalisation (cf. ibid.: 323324). An exploit or crime on the linear, fictional time plane was 
turned into a myth or epic cast into cyclical time, yet elevating at the same time some mythical "single lumps" - important and characteristic episodes related to the hero or anti-hero - above the linear duration of the whole. The handling of time, an attempt to accelerate or stop it in a story, is directly connected to how a person thinks and reflects or would like to reflect. The space where the events unfold or also some post-epic characters seem to be rather more mechanical categories. Through time, we are able to approach the obsessive question of the meaning of the songs.

In the interest of clarity, we might take the cue from psycholinguistics, defining the difference between sense and meaning in terms of an individual versus a collective.

The meaning of a word is a fixed system of generalisations held in common by all individuals, a system that may vary as to its depth, degree of generalisation, coverage of signified objects, yet will always retain a certain core - an unchanging set of associations. Side by side with "meaning", we can identify another conception usually termed "sense". Unlike meaning, sense signifies the individual meaning of the word isolated from the objective system of associations. It consists of the associations connected with the given moment and situation. (Luria 1979: 53).

It seems that the attempts to look beyond the formal aspect of the Kalevala-metric poetry - into their mythology and mentalities have dealt primarily with meaning. The locus of meaning in them inevitably lies in - or is placed into - a remoter past, but simultaneously, for objective reasons, also farther from the individual. The impact of the text on the individual, the way a song has addressed a singer or a listener, is one of the central and, by now, probably one of the least solvable problems.

Speaking about the points of contact of the narrator and the narrated world, the term epiphany can be useful for discussing time in Kalevala-metric poetry. "Epiphanies are points where the narrator grafts his world-view upon the inside of the story, through connecting the story's centres of gravity" (Annus 2002: 297). It seems highly reasonable that without such points of contact, epic poetry in general and lyrical song in particular might be altogether unable to address the individual. Whereas in more epic prose discourses, 
epiphanies may occur as artistically important but not exactly obligatory elements, they seem to be inevitable in the basically lyrical treatments in order to bring the performance and the performed to life primarily for the singer himself.

Here we can only briefly refer again to the pathos of the Estonian Kalevala-metric poetry studies of certain decades, which frequently and for good reasons liked to emphasise not only a song's connection to the demands of practical life, but also the singer's highly personal relationship to what he sang (see, for example, Laugaste 1975: 131). Although the epiphanic relation of the narrator to the narrated is well imaginable also in the case of epics - especially in certain culminating situations, either military or ritual, when people have felt the need for some inspirational support - it would, from our modern viewpoint, still seem to be a device for the more lyrical mode of expression. Speaking about the Setu Kalevala-metric poetry, Leea Virtanen has said that the singer's personal relation to and empathy for the subject of the song forms the very heart of the performance (see Virtanen 1994: 242). In case of the newer, completely ballad-like end-rhymed folk song, the performance of which may often have indeed constituted an ardent, mentally intense assimilation of the singer and the romantic hero, the epiphanic relation may be even more significant.

The modern entertainment industry is skilled at consciously calling forth such moments of assimilation - nowadays between text/ film and the recipients. TV-serials certainly owe their success and necessity to the fact that viewers are given a clear opportunity to identify themselves effortlessly with some (usually perhaps) positive character and the events befalling him. This is a well operating emotional rapport relying on feelings rather than mental processes. Since people tend to have ever greater problems of identification in a world requiring ever greater individualisation, these productions offer gratifying ready-made models. I think it is safe to say that each full-length Disney cartoon has been "programmed", at least in certain culminating episodes, to evoke in the audience noble zeal even to the extent of cathartic tears.

The completely lyrical Kalevala-metric poetry also appears to happen (and operate) in and for the moment. Its meaning lies either in an outward-oriented manifestation via the text or an inward-ori- 
ented contemplation through the text. Various interpretations can be imposed onto lyricism upon the reception of the same performance. Thus, "songs may be seen, for instance, primarily as proverbialized expressions of typical dilemmas but secondarily as depictions reminicent of personal experiences" (DuBois 1996: 259). The thematic field of lyrical Kalevala-metric poetry is very broad. On the manifestational side, we find primarily texts that either praise someone's personal skills (a talent for singing, for instance) or berate socially better placed persons. On the contemplative side, stories treating the dark side of personal lives prevail - the orphan songs probably being the most expressive here. The lyrical songs associated with calendrical or other events appear either to aim at some manifestation (cf. the singing competitions of kin groups at weddings) or to make comment on some event, the amount of information in them being approximately comparable to that contained in a memorate; that is, formally they resemble single statements rather than stories.

This concentration of self-expression or contemplation into just one moment is in a way (perhaps secondarily) inspirational. Inspiration, however, is a means for perceiving the eternal. Here we can observe the dual nature of lyricism - a momentary explosion creates links that reach much farther. In this respect, traditional lyricism is and will remain ritual. Even if the textual time is at a standstill or seems to have vanished altogether, the inspirational moment of performance is nevertheless situated in a vast plain of duration. A similar "inner conflict" seems to manifest itself even better in the Latvian dainas, but certainly also in all other genres that employ poetic parallelism as a stylistic device. In a suitable situational community, a formally lyrical quatrain conveying an apparently trivial episode will constitute a mystical crystal globe or time machine linking in a flash the individual to the universal. Thus, dainas are proverbial generalisations rather than narrative ballads, conveying their message in some kind of "eternal present" (cf. VīḳisFreibergs 1989: 9) instead of a past-to-future linearity. Their meaning can go well back to the Indo-Germanic mythology, whereas their sense in the present is realised, as it were, in a second. And again: what is time like in the Kalevala-metric epic poetry? Is it mythicalparallelistic, linear or momentary? 
In this situation, the confusion is made even worse by temporal parallelism appearing in the form of gradations - a central stylistic device of the Kalevala-metric poetry interpretable both as demarcating the sequential ordering of time units and as temporal simultaneity. The relatively small amount of parallelism in the Votic songs discussed here indicates probably (as compared to the Estonian examples) their lesser exposure to the lyrical discourse. It seems rather more likely that parallelism as such has never been used mechanically to indicate the course of one type of time or another, but has rather constituted a symbolic device, a poetic sêma for the insiders of the tradition. In the mythical archetypy of the Kalevala-metric poetry, a fixed number of repetitions of a similar content may, for instance, have marked knowledge of the completion of some cosmically determined time cycle, as Janīna Kursīte (1999: 557) has suggested for the Latvian dainas. The same should be valid for parallelisms concerning person or action, which should rather be taken back to some underlying sign than to literal degrees of particularity.

\section{CREATING MEANING IN THE LYRICAL DISCOURSE}

Reflecting on the time conception in the Kalevala-metric poetry, it thus appears unlikely that the temporal and fictional story should be primary in the above Votic songs, although they do contain an observable sequence of events in time: the girls come out into the market place while snow is falling; they begin to play; next, the playthings roll onto the grave and communication with dead brother begins. Yet it is quite clear that the main theme of the story is not the adventure in time (which it is somehow important to keep track of, arithmetically) but rather the problematic issue that follows the events: whether, and to what extent, is it reasonable and useful to communicate with the world beyond in pursuit of one's personal interests. It is possible and even likely that the central problems in the Estonian necromantic songs (as well as in the similar Setu songs) were the desolation of the orphan or the bride's invitation to take part in (or to be of help) at the critical rite of passage, the wedding.

The dialogue at the grave in these songs indisputably constitutes the "centre of gravity" for the orphan, as well as for a religious or 
tradition-respecting person in general. Yet nothing excludes the possibility that for some other singer or listener, the epiphanic recognition and thus also the relevance of the song may have appeared in the game episode - recalling, for instance, the happy days of youth spent in girls' company; or else in the opening image of snow falling - a poetic description of nature bringing forth powerful associations. Oral performing culture prefers to work with half independent units of form and content not too conducive to a fluent course, rather than operate with the sophisticated explanations and developments characteristic of literary novels. The Votic songs also have relatively few "events taking place" - what really takes place is just a very long and very personal epiphanic moment. Thus, in oral culture, the epiphanic relation is one of the central paths connecting the individual with the text unit(s) and naturally offering an advantage to creative minds who are better capable of handling the given material, not mere victims of folklore.

For a creative person, epiphany is a connection between

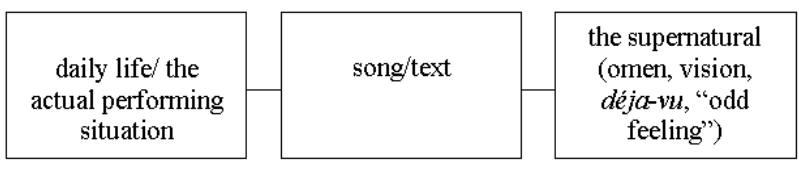

both on a very personal and on a culturally acquired level.

Thus, it is the collision and confusion of very different modes of comprehension that makes it so difficult for us to understand the Kalevala-metric epic poetry. The poorly understandable time conception on the border area between epic and lyrical cognition may have been the main reason why these action-based stories began to erode. With the erosion of the logical follow-ups of action (and of the stories thus formed), the individual characters (who had names) disappeared and the formerly well-defined stories lost relevance. What remained - moods and mentalities - was basically supported by spatially dictated situations and the singers' emotional recognitions captured within temporally static fossils. Instead of the text, understanding now depends more and more on the interpretation, which tends rather to wander off into individualism than 
to remain under collective control. Thus, the time of the Kalevalametric epic poetry is a lyrical time moment expanded by epiphanic cataclysms and "spoiled" by parallelisms. Epiphany, however, has demanded more and more creative effort. Thus, the growing distance of the relevant tradition from the general, more inert social body and its control mechanisms may have formed the backdrop for the erosion of the Kalevala-metric song tradition.

\section{Acknowledgements}

The article was written within the grant project of the Estonian Science Foundation (grant No. 4939).

\section{References}

Annus, Epp 2002. Kuidas kirjutada aega. Oxymora 5. Tallinn: Underi ja Tuglase Kirjanduskeskus.

DuBois, Thomas 1996. Native Hermeneutics: Traditional Means of Interpreting Lyric Songs in Northern Europe. Journal of American Folklore. Vol. 109, No. 433, pp. 235-266.

ERlA $\mathrm{II}_{2}=$ Eesti rahvalaulud. Antoloogia II, 2. Ü. Tedre (Ed.). Tallinn: Eesti Raamat, 1970.

Foley, John Miles 1991. Immanent Art. From Structure to Meaning in Traditional Oral Epic. Bloomington: Indiana University Press.

Honko, Lauri 1998. Textualising the Siri Epic. FFC 264. Helsinki: Suomalainen Tiedeakatemia.

Kursīte, Janīna 1999. Müütiline aeg läti folklooris. Keel ja Kirjandus, No. 8, pp. 551-559.

Kuusi, Matti 1994. Questiones of Kalevala Metre. Songs Beyond the Kalevala. Transformations of Oral Poetry. A.-L. Siikala \& S. Vakimo (Eds.). Studia Fennica. Folkloristica, Vol. 2. Helsinki: Suomalaisen Kirjallisuuden Seura, pp. 41-55.

Laugaste, Eduard 1975. Eesti rahvaluule. Tallinn: Valgus.

Lintrop, Aado 2001. "Ema haual" lego ja lauluna. Regilaul - keel, muusika, poeetika. T. Jaago \& M. Sarv (Eds.). Tartu: Eesti Kirjandusmuuseum, pp. 299-313.

Lotman, Juri 1991. Kirjandus ja mütoloogia. Kultuurisemiootika. Tallinn: Olion, pp. 317-346.

Lotman, Iurii 2001. O mifologicheskom kode siuzhetnykh tekstov. Semiosfera. Sankt-Peterburg: Iskusstvo-SPB, pp. 670-673.

Luria, Alexandr 1979. Iazyk i soznanie. Moskva: Izdatel'stvo Moskovskogo universiteta. 
Merilai, Arne 1996. Eesti ballaadi ajamudelid. Kirjandusteadus. Mõte ja ulm, rakendus ja uurimus. Tartu Ülikooli eesti kirjanduse õppetooli toimetised, Vol. 1. Tartu: Tartu Ülikooli Kirjastus, pp. 13-28.

Nenola-Kallio, Aili 1982. Studies in Ingrian Lamnets. FFC 234. Helsinki: Suomalainen Tiedeakatemia.

Salminen, Väinö 1929. Tutkimus vatjalaisten runojen alkuperästä. Suomi V, 7. Helsinki: Suomalaisen Kirjallisuuden Seura,

Siikala, Anna-Leena 2002. Mythic Images and Shamanism. A Perspective on Kalevala Poetry. FFC 280. Helsinki: Suomalainen Tiedeakatemia.

SKVR $\mathrm{IV}_{3}=$ Suomen kansan vanhat runot IV, 3. Keski-Inkerin ja vatjalaiset runot. V. Salminen (Ed.). Helsinki: Suomalaisen Kirjallisuuden Seura, 1928.

Valk, Ülo 2000. Regilaul kui kommunikatsioon teispoolsusega: dialoogist nägemuseni. Kust tulid lood minule... Artikleid regilaulu uurimise alalt 1990. aastatel. T. Jaago \& Ü. Valk (Eds.). Tartu: Tartu Ülikooli kirjastus, pp. $245-276$.

Vīkis-Freibergs, Vaira 1989. Oral Tradition as Cultural History in the Lyrical World of the Latvian Daina. Linguistics and Poetics of Latvian Folk Songs. V. Vīkis-Freibergs (Ed.). Kingston \& Montreal: McGill-Queen's University Press, pp. 3-13.

Virtanen, Leea 1994. Singers on their songs: the act of singing as perceived by singers in the Setu region of Estonia today. The Uses of Tradition. A Comparative Enquiry into the Nature, Uses and Functions of Oral Poetry in the Balkans, the Baltic, and Africa. M. Branch \& C. Hawkesworth (Eds.). London: School of Slavonic and East European Studies, University of London; Helsinki: Finnish Literature Society, pp. 231-249. 